\title{
The Effect of Organizational Climate on Quality of Work Life With Job Stress as a Mediation Variable
}

\author{
Ni Komang Enny Trisnayanti Agoes Ganesha Rahyuda \\ Faculty of Economic and Business Udayana, University, Bali, Indonesia
}

\begin{abstract}
The sample used is the employees of the Bank Indonesia Representative Office of Bali Province, amounting to 70 respondents with sample collection techniques using a sampling census. This study uses PLS (Partial Least Square) analysis techniques. The results of the study found that the organizational climate has a positive effect on quality of work life. Job stress has a negative effect on quality of work life. Organizational climate has a negative effect on job stress, and job stress as a mediator has a significant effect on organizational climate relations and quality of work life. The implications of this study indicate that employees need quality of work life in organizations where it is necessary to consider the prevailing working hours to be in accordance with the legal standards that have been validated, so that employees are able to create synergic relationships between work and other environments. Furthermore, the organization's climate also needs to be considered by the organization in order to fulfill a conducive working atmosphere where organizational support needs to be built, clarity of work, self-expression, making contributions, awards and finally the challenges in the organization.
\end{abstract}

Keywords: Organizational climate, job stress, quality of work life

DOI: $10.7176 /$ EJBM/11-24-03

Publication date: August $31^{\text {st }} 2019$

\section{INTRODUCTION}

In maintaining stability and economy, it cannot be separated from the role of employees who work in it to grow and develop within the organization. So from that the organization must be able to create situations and conditions that encourage employees to develop abilities and skills optimally and train employees and set organizational goals (Dessler, 2011: 322).

The problem that arises is that when mismanagement of human resources will cause a decrease in quality of work life for employees. According to Mangkuprawira (2009), quality of work life is a level of satisfaction, motivation, involvement and experience of individual commitment regarding their lives at work. Quality of work life also means the degree to which individuals are able to satisfy their individual needs. According to Richard E. Walton cited in Triatna (2012) quality of work life is: adequate and reasonable compensation, safe and healthy conditions, opportunities to develop and use human capacity, opportunities for sustainable growth and assurance, feelings included in a group, employee rights, work and overall work space and social relevance of work life.

The success of the company depends on how employee performance, efficiency, honesty, perseverance and integrity (Ahmed and Uddin, 2012). But the importance of quality of work life encourages KPwBI Province of Bali to give attention to this concept, it turns out there are still some problems related to quality of work life in $\mathrm{KPwBI}$ in Bali Province. According to interviews and preliminary observations made on the employees of KPwBI Bali Province, it can be concluded that there are indications of problems related to quality of work life. This can be seen from the existence of working hours that exceed the standard work time, they spend quite a lot of time together with coll

eagues, both superiors and other coworkers. The normal working time of KPwBI in Bali Province is Monday-Friday at 08.00 - 17.00. The working hours do not rule out the possibility that an employee must run overtime or work on a day off to work on a particular project, so that employees feel an uncomfortable working environment which will directly affect the organization's climate and quality of work life for employees. The second problem is the lack of social relevance where employees are unable to create synergic relationships between work and other living environments as well as relationships with family at home, even community relationships. The third problem arises between fellow colleagues, namely in social integration where among fellow workers do not have a synergistic relationship and do not have cohesiveness, because each individual trying to be the best and stand out in their work. From the above description it can be concluded that the KPwBi Bali has a poor quality of work life.

Based on the literature studied, one of the factors that effect employees in improving quality of work life is organizational climate factors. Organizational climate according to Singh (2011) is a relatively lasting quality of the organization experienced by its members; it has an effect on their behavior, and how it works. Organizational climate is divided into two parts, namely the environmental conditions of the organization that relate to the physical and environmental conditions of psychic or non-physical organizations. Physical work environment conditions are all work environments that are related to their physical aspects. Whereas the non-physical work environment conditions are all activities that occur in the work environment relating to psychological 
relationships, both relationships with superiors and fellow colleagues (Pasrah and Meyzi, 2013). From the results of interviews and preliminary observations of the problems related to the organizational climate in the KPwBI, the psychological meaning included challenges, the employees felt that the level of pressure imposed by the organization to improve performance was a lot of things in the form of thoughts and ideas made by employees to make KPwBI Bali Province even better.

Following are some studies that show the role of organizational climate effect to quality of work life. Selamat et al. (2013), Suliman and Harethi (2013), Suandi et al. (2014), and He et al. (2015) who found that the high and low quality of work life in employees was directly affected by the health or absence of the organizational climate in the company. Organizational climate plays a direct role in improving individual behavior and performance (He et al., 2015). Employees who are faced with a conducive work climate have made information sharing, positive management support, contribution and involvement in the decision-making process tend to have a positive impact on the quality of work life of their workers. Employees who understand and feel an adequate, safe and pleasant work environment will develop a positive attitude towards various components of work which ultimately results in higher work involvement and performance (Suliman and Harethi, 2013). Working in a closed and unhealthy organizational climate brings emotions negative feelings and feelings by employees, this includes dissatisfaction, psychological distress, neglect, indifference, and ultimately will cause employees to avoid work that leads to job stress (Ahghar, 2008).

The effect of organizational climate on quality of work life is also due to the effect of job stress variables. Stress is a negative emotional state that occurs in response to events that are considered heavy or exceeding one's resources or the ability to overcome them (Hockenbury and Hockenbury, 2010). Furthermore, Gibson et al. (2012) define stress as an adaptive response mediated by individual differences and / or psychological processes resulting from each activity, situation, or event that imposes excessive psychological and / or physical demands on a person. Stress has increased due to growing needs, intense competition, work pressure and a short period of time. When job stress is felt, it will not only affect work performance but also affect employee health in the form of heart attacks, migraines that can cause death. (Yahaya, et.al 2010). Stress has become a major part of modern human life. This continues to pose threats and challenges to one's health and well-being. With the current state of uncertainty, pressure, frustration, demands and failures that are felt continuously at work make stress unavoidable (Estrella, 2014).

\section{LITERATURE REVIEW AND HYPOTHESES}

Increasingly tight business competition requires companies to be able to compete with other organizations. In order to be competitive, companies must be able to create quality of work life for employees in the organizational structure so that it can become a competitive advantage. Richard E. Walton quoted in Triatna (2012) quality of work life is: adequate and reasonable compensation, safe and healthy conditions, opportunities to develop and use human capacity, opportunities for sustainable growth and assurance, feelings included in the situation group, employee rights, work and overall work space and social relevance of work life. Without a quality workforce sustainable competitive advantage will be difficult to achieve, because employees as the spearhead of the company in creating a valuable organization (Schonewille, 2014).

To improve the quality of work life is inseparable from increasing the climate of citizenship for employees. If the company has a good organizational climate, the company will be easier to create a conducive atmosphere for the quality of work life of employees. Organizational climate according to Singh (2011) is a relatively lasting quality of the organization experienced by its members; it has an effect on their behavior, and how it works.

Every organization wants an emphasis on the high stress of employee work on the company. Because this can be defined as a decrease in physical and mental employees caused by the danger they feel. Stress is a negative emotional state that occurs in response to events that are considered heavy or exceeding one's resources or the ability to overcome them (Hockenbury and Hockenbury, 2010). Furthermore, Gibson et al. (2012) define stress as an adaptive response mediated by individual differences and / or psychological processes resulting from each activity, situation, or event that imposes excessive psychological and / or physical demands on a person.

\section{Hypothesis}

H1: Organizational climate has a positive effect on quality of work life.

$\mathrm{H} 2$ : Organizational climate has a negative effect on job stress.

H3: Job stress has a negative effect on quality of work life.

H4: Job stress mediates the effect of organizational climate on quality of work life

\section{METHODS}

To obtain the data to be examined, researchers used data collection techniques using questionnaires and used the Likert scale to measure attitudes, opinions and respondents' perceptions of organizational climate, job stress and quality of work life. 
The population used in this study were all employees of KPwBI in Bali Province, namely 131 employees. The method of determining the sample in this study was carried out by sampling census. The criteria used in selecting samples in this study are employees who are NRP status (permanent employees) and those who are not included as leaders. Based on these criteria, there were 70 employees who met the requirements as a sample.

Hypothesis testing using the $t$ test. Tests carried out by t-test on the inner model obtained p-value 50.05 (alpha 5\%), the test means that there is a significant effect of latent variables namely organizational climate variables on other latent variables, namely the variable quality of work life and job stress.

\section{RESULTS AND DISCUSSION}

Evaluation of the Structure Model or Inner Model

Structural models were evaluated using R-square for the dependent construct and test and the significance of the structural path parameter coefficients.

Table1.

R-square

\begin{tabular}{lll}
\hline \multicolumn{2}{c}{ Construct } & R-square \\
\hline Quality Of Work Life & 0,623 & \\
Job Stress & 0,329 & \\
\hline
\end{tabular}

Data Primer, 2019

In table 1 it can be seen if the R-square value of the quality of work life variable is 0.623 . This can be interpreted that $62.3 \%$ of the construct variability of quality of work life is explained by job stress variables and organizational climate while $37.7 \%$ of the quality of work life variables are explained by variables outside the model. Likewise, with job stress variables, $32.9 \%$ of the variability is explained by organizational climate, while $67.1 \%$ of job stress variables are explained by variables outside the model.

In addition to using R-square, goodness of fit, the model is also measured using Q-Square predicated relevance for structural models, measuring how well the observations produced by the model and also its parameter estimates. Q-Square value $>0$ indicates the model has predicate relevance, whereas if the Q-Square value $\leq 0$ indicates the model does not have predicate relevance. Based on Table 1 the calculated value of relevance $\left(\mathrm{Q}^{2}\right)$ can be calculated, namely:

$$
\begin{aligned}
Q^{2}=1- & \left(1-R 1^{2}\right)\left(1-R 2^{2}\right) \\
= & 1-(1-0,623)(1-0,329) \\
& =1-(0,377)(0,671) \\
& =1-0,252 \\
& =0,747
\end{aligned}
$$

The results of this calculation indicate that the value of $\mathrm{Q}^{2}$ is greater than $0(0.747)$, so it can be interpreted that the model is good because it has a relevant predictive value, which is equal to $74.7 \%$. This shows that variations in the quality of work life variables can be explained by the variables used, namely organizational climate and job stress, while the remaining $25.3 \%$ is explained by other variables that have not entered the model.

\section{Hypothesis testing}

The significance of the estimated parameters provides very useful information about the relationship between the research variables. The basis used in testing the hypothesis is the value found in the output path coefficients presented in Table 2 below:

Table 2.

Path Coefficients

\begin{tabular}{lccc}
\hline Constructs & Path Coefficient & t statistics & Description \\
\hline Climate Organization -> Quality of Work Life & 0,282 & 2,390 & Accepted \\
Climate Organization -> Job Stress & $-0,574$ & 6,570 & Accepted \\
Job Stress -> Quality off Work Life & $-0,593$ & 5,620 & Accepted \\
\hline
\end{tabular}

Data Primer, 2019

Hypothesis testing is done using t-statistics. If the value of t-statistics $\geq \mathrm{t}$-table value (1.96), then Ho is rejected and the research hypothesis is accepted. In Table 2 it can be seen that the organizational climate has a correlation coefficient of 0.282 and t statistics of 2.390. This shows if there is a positive influence between organizational climate on quality of work life. The more conducive the organizational climate is created, the higher the quality of work life created by an organization. Organizational climate variable has a correlation 
coefficient of -0.574 and the value of $t$ statistics is 6.570 . This shows if there is a negative influence between organizational climate on job stress. This indicates that the healthier the climate of an organization, the lower the level of job stress of employees. Conversely, the more-unhealthy the climate of an organization, the higher the level of job stress of employees. Furthermore, the job stress variable has a correlation coefficient of -0.593 and the value of $t$ statistics is 5.620. This shows if there is a negative influence between job stress on quality of work life. This shows that employees who have high job stress will tend to have low performance. Conversely, employees with low job stress will tend to have high performance. Based on the data above, it can be concluded that the hypothesis in one study was accepted and two were rejected.

The Role of Job Stress Mediation in Organizational Climate to Quality of Work Life

The direct effect test results show that the coefficient between organizational climate variables on quality of work life is 0.282 with a t-statistics value of 2.390 . The addition of job stress variables as mediating variables gives a different effect on the direct relationship of organizational climate to quality of work life. The testing of job stress mediating variables is done by calculating the value of Variance Accounted For (VAF) which can be seen in Table 3.

Table 3.

Diret Effect, Indirect Effect,

\begin{tabular}{lcc}
\hline \multicolumn{1}{c}{ Variable } & Direct Effect & T Statistic \\
& Coefficient & (|O/STDEV|) \\
\hline Climate Organization -> Quality of Work Life & & 2,390 \\
Climate Organization -> Job Stress & 0,282 & 6,570 \\
Job Stress -> Quality off Work Life & $-0,574$ & 5,620 \\
\multicolumn{1}{c}{ Variable } & $-0,593$ & 5,140 \\
Climate Organization -> Quality of Work Life & Indirect Effect & Total Effect \\
Variable & 0,340 & 6,718 \\
Climate Organization -> Quality of Work Life & 0,623 & 6,570 \\
Climate Organization -> Job Stress & $-0,574$ & 5,620 \\
Job Stress -> Quality off Work Life & $-0,593$ & 0,545 \\
VAF & Indirect Effect / Total Effect (0,340/0,623)
\end{tabular}

Data Primer, 2019

From the results of calculations in Table 3 it can be interpreted that the role of job stress as a mediator has a VAF value of $0.545(54.5 \%)$. These results indicate that job stress variables have a mediating role that can be categorized as partial mediation because VAF is between $20 \%-80 \%$. This shows that one of the causes of high levels of job stress is an unhealthy organizational climate. Employees' perceptions about organizational characteristics that are reflected in policies, practices and conditions that exist in an unhealthy work environment will lead to negative emotions which will ultimately cause job stress felt by employees. Furthermore, employees who suffer from stress will try to withdraw themselves from the causes of stress by leaving the company and or not being present at work. If leaving the company is something that is difficult for employees, then they will create problems for the company such as inefficiencies in performance, waste of operational resources, causing work constraints for other employees. All of this will greatly affect the organizational climate and quality of work life so the hypothesis stating that job stress acts as a mediator of the relationship between organizational climate and quality of work life is proven.

\section{The Effect of Organizational Climate on Quality of Work Life}

Based on the data presented in Table 2 it is known that the path coefficient shows that the organizational climate has a positive influence on the quality of work life. This shows the more conducive organizational climate that is created, the better the quality of work life created by an organization. The results of this study prove that the quality of work life in KPwBI Bali Province is good because based on the description of respondents' answers, all indicators have a good value and are very good where the environmental safety indicators ie employees feel the working environment is not in accordance with applicable working hours standards as evidenced by the 
number of overtime that must be done by employees, as well as working during holidays, so that the impact on the assessment of employees with the lowest answer results. Furthermore, the indicator of available facilities is that employees feel the facilities provided are already very supportive of future employee careers as evidenced by having the highest respondent's answer. Therefore, the quality of work life of KPwBI Bali Province is good.

These findings indicate that the organizational climate felt by employees will affect the quality of work life of employees including employees being able to create a synergistic relationship between work and other environmental aspects, fellow workers have a solidarity at work and employees feel responsible for their work, the higher the perceived organizational climate is also getting higher the quality of work life that is generated

The results of this study are in line with research conducted by several studies that organizational climate has a positive and significant effect on the quality of work life of employees (Adeyemi, 2008; Selamat et al., 2013; Suliman and Harethi, 2013; Suandi et al., 2014; He et al., 2015). This indicates that the more conducive (healthier) climate of an organization, the better the level of quality of work life of employees. Conversely, the less conducive (unhealthy) climate of an organization, the worse the level of quality of work life of employees.

\section{The Effect of Organizational Climate on Job Stress}

Based on the data presented in Table 2 it is known that the path shows that organizational climate has a negative influence on job stress. This indicates that the healthier the climate of an organization, the lower the level of employee job stress. at the Bali Province KPwBI. From the results of this study, it is proven that job stress in Bali Province KPwBI is high because based on the description of respondents' answers, all indicators have a high value where the role conflict indicator has the lowest respondent's answer value. Whereas organizational structure indicators namely overlapping organizational structure of command lines causes inconvenience in working to have the highest respondent answers. Therefore, stress on Bali Province KPwBI is included in the high category. The results of this study are in line with research conducted by (Ahghar, 2008; Putra et. Al., 2014; Sert et al., 2014). Aghar (2008) and Sert et al. (2014) that organizational climate has a negative effect on employee job stress. This indicates working in a closed and unhealthy organizational climate brings negative emotions and feelings for employees. This will cause dissatisfaction, psychological pressure, neglect, indifference, and will eventually cause employees to avoid work that leads to job stress. This indicates that the healthier the climate of an organization, the lower the level of employee job stress. Conversely, the more unhealthy the climate of an organization, the higher the level of employee job stress.

\section{The Effect of Job Stress on Quality of Work Life}

Based on the data presented in Table 2 it is known that the path coefficient shows that job stress negatively affects the quality of work life. This means that the higher the stress the employee has, the lower the quality of work life of the company. The results of this study prove that the stress of the Bali Province KPwBI is high because based on the description of respondents' answers, all indicators have a high value where the role conflict indicator has the lowest respondent's answer value. Whereas organizational structure indicators namely overlapping organizational structure of command lines causes inconvenience in working to have the highest respondent answers. Therefore, stress on Bali Province KPwBI is included in the high category. While the quality of work life of the Bali Province KPwBI is good, which can be seen from the indicators of the facilities available that have the highest respondent answers because the facilities provided are very supportive of employees in working, conversely, the working hours at KPwBI are not in accordance with applicable working hours standards so has the lowest respondent value. The results of this study are in line with research conducted by (Bashir and Ramay, 2010; Cholilawati, 2010; Jehangir et al., 2011; Leung et al., 2011; Abdillah, 2013; Suandi et al., 2014; Rangriz and Pashootanizadeh, 2014 ; Goswami, 2015). This shows that employees who have high job stress will tend to have low performance. Conversely, employees with low job stress will tend to have high performance.

\section{The Role of Job stress Mediation in Organizational Climate to Quality of Work Life}

Based on the data obtained in Table 2 shows that the coefficient value is negative. The addition of job stress variables as mediating variables gives a different effect on the direct relationship of organizational climate to quality of work life. Testing the company's job stress mediating variable is done by calculating the value of Variance Accounted For (VAF) which can be seen in Table 3. These results indicate that the job stress variable has a role as a mediator between the organizational climate and quality of work life, so the hypothesis stating that job stress acting as a mediating relationship between organizational climate and proven quality of work life. This shows that organizational climate and job stress are important factors in creating quality of work life in an organization.

The results of this study are in line with research conducted by (Ahghar, 2008; Putra et. Al., 2014; Sert et al., 2014). Employees' perceptions about organizational characteristics that are reflected in policies, practices and conditions that exist in an unhealthy work environment will lead to negative emotions which will ultimately 
cause job stress felt by employees (Schanke, 1983; Ahghar, 2008). Furthermore, employees who suffer from stress will try to withdraw themselves from the causes of stress by leaving the company and or not being present at work. If leaving the company is something that is difficult for employees, then they will create problems for the company such as inefficiency in performance, waste of operational resources, causing work constraints for other employees and so on (Goswami, 2015).

\section{CONCLUSION}

The results of this study have shown that organizational climate has a positive effect on quality of work life, organizational climate has a negative effect on job stress, job stress that has a negative effect on quality of work life and job stress has an effect as a mediator between organizational climate on quality of work life.

Based on these findings support the theory that the better the level of organizational climate can improve the quality of work life. In addition, a good organizational climate will reduce stress in the organization, as well as increasing job stress within the organization, which will reduce the level of quality of work life of the company. The results of this study are expected to be empirical evidence for future research and are able to enrich the development of human resource management knowledge related to organizational climate, quality of work life and job stress as mediating the influence of organizational climate on quality of work life.

Based on these results, there are two practical implications produced. First, quality of work life has a greater influence in determining organizational climate compared to job stress. This shows that employees need a good quality of work life in the organization which needs to be considered applicable working hours to conform to the legal hours that have been validated, so that employees are able to create a synergistic relationship between work and other environments.

Furthermore, the organizational climate also needs to be considered by the organization in order to fulfill a conducive work atmosphere where organizational support needs to be built, clarity on work, self expression, making contributions, appreciation and finally the challenges within the organization.

\section{Research Limitation}

1) The scope of the research is only limited to the KPwBI region of the Province of Bali so that the results of the study may also have differences regarding how perceptions or levels of interpretation of each respondent in the area of the Bank Indonesia Regional Office

2) This research is only limited to assessing organizational climate, job stress and quality of work life, so it cannot examine more deeply the factors outside these variables.

3) This research is related to the determination of the sample using the sansus sampling technique for future research can apply other sampling techniques, one of which is the random sampling technique so that it can be generalized.

4) This study uses a cross-sectional time design or at a specific point in time, but on the other hand this study observes the dynamics of conditions that have changed every period, because this research is important to be re-examined in the future.

\section{References}

Abdillah, M., R. (2013) Pengaruh Dimensi Kecerdasan Emosional Terhadap Stress Kerja dan Kinerja. Tesis Magister Manajemen Universitas Islam Indonesia: Yogyakarta (Tidak Dipublikasikan).

Adeyemi, T. O. (2008) “Organisational Climate and Teachers' Job Performance in Primary Schools in Ondo State, Nigeria: An Analytical Survey”. Asian Journal of Information Technology. 7 (4), 138-145.

Ahmed, Shaheen dan Md Nokir Uddin. 2012. Job Satisfaction of Bankers and its Impact in Banking: A Case Study of Janata Bank. Journal ASA University Review. 6(2): h:95-102.

Bashir, U. dan M. I. Ramay. (2010) "Impact of Stress on Employees Job Performance A Study on Banking Sector of Pakistan”. International Journal of Marketing Studies. 2 (1), 122-126.

Butler-Bowden, T (2001). 50 Self-Help Classics. Sydney, Australia: Simon \& Schuster.

Cascio, W.F. (2006). Managing human resources, productivity, quality of work life, profit (4th ed.). New York: Mc Graw-Hill.

Chadha,M., Sood,K \& Malhotra,S.,(2012) Effects of organizational stress on quality of life of primary and secondary school teachers. Delhi Psychiatry Journal. 15(2), 342-346.

Cholilawati, N. (2010) "Pengaruh Kecerdasan Emosional Terhadap Stress Kerja dan Kinerja Perawat di Rumah Sakit Islam Hidayatullah Yogyakarta”. Tesis Magister Manajemen, Universitas Islam Indonesia: Yogyakarta, (Tidak Dipublikasikan).

Dessler, Gary. 2011. Manajemen Sumber Daya Manusia. Edisi Kesepuluh, Jilid 1. Jakarta. Indeks.

Estrella, E. A. (2014) "Job Stress and Job Performance of The Faculty of Instruction of The College of Education of The Bulacan State University Bustos Teaching and Faculty Development. 5 (1), 1-10 Campus”. International Journal of University 
Firmansah, Moh.Irsan., dan Raeny Dwi Santy. 2011. Pengaruh Iklim Organisasi dan Karakteristik Pekerjaan Terhadap Kepuasan Kerja Pegawai di Lingkungan Pemerintahan Daerah Kabupaten Sukabumi. Majalah Ilmiah Unikom, 6 (2), h:225-232.

Freund, A M and P B Baltes (2002). Life-management Strategies of Selection, Optimisation and Compensation: Measurement by Self-report and Construct Validity. Journal of Personality and Social Psychology, 82 (4): 642-62.

Gibson, J.L., J. M. Ivancevich, J. H. Donelly Jr., dan R. Konopaske. (2012) Organizations: Behavior, Structure, Process. New York: McGraw-Hill.

Gibson, Ivan Cevich dan Donhelly. 1993. Organisasi Jilid 1. Terjemahan : Dark asih. Erlangga, Jakarta.

Goswami, T. G. (2015) “Job Stress and Its Effect on Employee Performance in Banking Sector”. Indian Journal of Commerce \& Management Studies. 6 (2), 51-56.

Gaffar, hulaifah. 2012. Pengaruh Stres Kerja Terhadap Kinerja Karyawan. Sripsi Fakultas Ekonomi dan Bisnis Jurusan Manajemen Universitas Hasanud din: Makassar.

Hair, J.F., Anderson, R.E., Tatham, R.L. dan Black W.C. 2010. Multivariate Data Analysis 4th Edition. New Jersey: Prentice-Hall.

He, Q., Q. An, dan M. Li. (2015) “How Vocational Delay of Gratification Affects Employees' Job Performance: Organizational Climate as a Moderator". Journal of Service Science and Management. 8 (5) (October), 766772.

Hockenbury, D. H. dan S. E. Hockenbury. (2010) Psychology. Fifth Edition. New York: Worth.

Hughes, C and S V Scott (1998). Teaching Self-management in Employment Settings. Journal of Vocational Rehabilitation, 8 (1): 43-53.

Jaya, I., and Sumertajaya, I. 2008. Pemodelan Persamaan Struktural Dengan Partial Least Square. Semnas Matematika dan Pendidikan Matematika.

Jehangir, M., N. Kareem, A. Khan, M. T. Jan. (2011) "Effects of Job Stress on Job Performance \& Job Satisfaction”. Interdiciplinary Journal of Contemporary Research in Business. 3 (7) (November), 453-456.

Kasraie Sh, Parsa Sh, Hassani M, Ghasem-Zadeh A. (2014) To investigate the Re lationship between Quality of work life, Job stress, Job Satisfaction and Citizenship Behavior in Oshnaviyeh Hospital's staff. Pateint Saf Qual Improv Journal, 2(2),77-81.

Kanpur, R., \& Srivastava, S. (2014). A Study On Quality Of Work Life: Key Elements \& It's Implications. Journal of Business and Management, 54-59.

King, Z (2001). Career Self-management: A Framework for Guidance of Employed Adults. British Journal of Guidance and Counselling, 29 (1): 65-78.

Kumar, D., \& Deo, M.J. (2011) Stress and work life of College teachers. Journal of the Indian Academy of Applied Psychology. 37(Special issue), 78-85.

Leung, M., Y. S.I. Chan, dan C. Dongyu. (2011) Structural linear relationships between job stress, burnout, physiological stress, and performance of con struction project managers. Engineering, Construction and Architectual Management. 18 (3), 312-328.

Lorig, K R and H R Holman (2003). Self-management Education: History, Definition, Outcomes and Mechanism. Annals of Behavioural Medicine, 26 (1): 1-7.

Luthans, Fred. 2011. Organizational Behavior : An Evidence-Based Approach. New York: McGraw-Hill.

Mangkunegara, A. A. A. P. (2010) Manajemen Sumber Daya Manusia Perusahaan. Bandung : Rosda.

Miller, J. (2002) Creating a work climate that motivates staff and improves per formance. The Manager. 11 (3): $1-21$.

Mangkuprawira, S dan Aida V. Hubeis. 2009. Manajemen Mutu Sumber Daya Manusia. Ghalia Indonesia. Bogor.

Mohsan, F., M. M. Nawaz, M. S. Khan. (2011) "Impact of Stress on Job Performance of Employees Working in Banking Sector of Pakistan”. Interdici plinary Journal of Contemporary Research in Business. 3 (2) (June), 1982-1991.

Nanjundeswaraswamy, T. S., \& Swami, D. R. (2013). Review of Literature on Quality of Work Life. International Journal of Quality Research, 7(2), 201-214.

Nawawi, 2011, Manajemen Sumber Daya Manusia: Untuk Bisnis Yang Kompetitif, Gajahmada University Press, Yogyakarta

Oades, L G, P Caputi, P Robinson B Patridge (2005). A Contemporary Coaching Theory to Integrate Work and Life in Changing Times. In M Cavanagh, A Grant and T Kemp (eds), Evidence Based Coaching. Bowen Hills, Qld, Australia: Australian Academic Press. Pp 69-82.

Pasrah, Romi \& Meyzi Heriyanto. 2013. Kompetensi Kerja, Iklim Organisasi, dan Penempatan Pegawai. Jurnal Kebijakan Publik Pekanbaru. 4(1): h:37-42.

Putra, A. U., E. S. Astuti, dan D. Hamid. (2014) "Pengaruh Iklim Organisasi ter hadap Eustress dan Kepuasan Kerja Karyawan (Studi Kasus Pada Karyawan Perum Jasa Tirta I Malang Jawa Timur)". Jurnal 
Administrasi Bisnis. 14. (1) (September), 1-10.

Rahimic, Zijada. 2013. Influence of Organizational Climate on Job Satisfaction in Bosnia and Herzegovina Companies. International Business Research, (3), pp: 129-139.

Rangriz, H. dan H. Pashootanizadeh. (2014) "The Relationship between Job Stress, Job Satisfaction, and Employee Performance". Asian Journal of Research in Social Sciences and Humanities. 4 (10) (October), 353-363.

Robbins, S. R. (2007) Perilaku Organisasi, Edisi Kesepuluh, Cetakan Kedua. Jakarta: Indeks.

Robbins, S. 2008. Perilaku Organisasi, Jilid I dan II, alih Bahasa : Hadyana Puja atmaja. Jakarta: Prenhallindo.

Robbins, S.P dan Timothy A. Judge. (2015). Perilaku Organisasi, Edisi 16. Jakarta: Salemba Empat.

Sert, A., M. Elçi, T. Uslu, dan I. Şener. (2014) The Effects of Organizational Jus tice and Ethical Climate on Perceived Work Related Stress. Procedia Social and Behavioral Sciences. 150 (September), 1187-1198.

Schonewille, M. 2014. Perceived CSR and organizational attractiveness: the influence of personal values, age and gender. Thesis Universiteit Van Amsterdam.

Selamat, N., N. Z. Samsu, dan N. S. M. Kamalu. (2013) The Impact of Organizational Climate on Teachers' Job Performance. Educational Research eJournal. 2 (1), $71-82$.

Shadur, M., R. Kienzle, dan J. J. Rodwell. (1999) The relationship between organizational climate and employee perceptions of involvement. Group \& Organization Management. 24 (4) (December), 479-503.

Sheel, S. (2012). Quality of work life, employee performance and career growth opportunities: A literature review. Zenith International Journal of Multidisciplinary Research, 2, 2, 291-300.

Smith, J (1999). Life-planning, Anticipating Future Life Goals and Managing Personal Development. In J Brandstadter and R M Lerner (eds), Action and Self-development Theory and Research through the Lifespan. Thousand Oaks: C A Sage. Pp 223-255.

Siagian, Sondang. P. 2014. Manajemen Sumber Daya Manusia. Jakarta: Bumi Aksara.

Singh, R. Reecha., Amit Chauhan, Sangeeta Agrawal \& Saurabba Kapoor. 2011. Impact Of Organisational Climate On Job Satisfaction A Comparative Study. International Journal of Computer Science and Management Studies. 11(2): h: 9-18.

Stringer, Robert. 2002. Leadership and Organizational Climate. Prentice Hall. New Jersey

Suandi T., I. A. Ismail, dan Z. Othman. (2014) "Relationship Between Organizational Climate, Job Stress And Job Performance Officer At State Education Department”. International Journal of Education \& Literacy Study 2 (1) (January), 17-28.

Suliman, A. dan B. A. Harethi. (2013) Perceived work climate and employee performance in public security organizations in the UAE. Transforming Government: People, Process and Policy. 7 (3), 410-424.

Umam, Khaerul. 2012. Manajemen Organisasi. Bandung: Pustaka Setia.

Wibowo. 2013. Manajemen Kinerja. Jakarta: Rajawali Pers

Wirawan. 2008. Budaya dan Iklim Organisasi. Jakarta. Salemba Empat

Wiyono, G. 2011. Merancang Penelitian Bisnis dengan Alat Analisis SPSS 17.0 dan Smart PLS 2.0. Yogyakarta: STIM YKPN.

Yahaya,N., Yahaya,A., Tamyes, FA., Ismail, J. \& Jaalam,S., (2010). The Effect of various modes of occupational stress, job satisfaction, intention to leave and absentism companies commission of Malaysia. Australian Journal of basic and applied sciences, 4(7), 1676- 1679.

Yustrianthe, Rahmawati Hanny. 2008. Pengaruh Flexible Work Arrangement Ter hadap Role Conflict, Role Overload, Reduced Personal Accomplishment, Job Satisfaction, Dan Intention to Stay. Jurnal Bisnis Dan Akuntansi, Vol. 10 No. 3, Hal : 127 - 138. 